\title{
A Preview of Coming Attractions
}

\section{The Proposed New Standards for ATS Accreditation}

Mitzi J. Budde, Virginia Theological Seminary

\begin{abstract}
The Association of Theological Schools (ATS) is the accrediting body for graduate theological education in the US and Canada. The ATS standards for accreditation have been rewritten and the proposed new standards will be voted on at the ATS biennial conference on June 24,2020 . This session reviews five key changes in the proposed new standards and discusses the proposed new standard on library and information services.
\end{abstract}

\section{SITUATION}

The Association of Theological Schools (ATS) is the accrediting body for graduate theological education in the US and Canada. In this session on the proposed new ATS Standards for Accreditation, I plan to address four topics: 1) What's happening with the ATS Standards? 2) What's different about the new standards, in general? 3) What's different in the library standard specifically? 4) How will the changes be implemented?

If you have experienced a self-study process and accreditation visit based on the ATS 1996 Standards, you may have encountered some of the ways in which those standards have become outdated, particularly around online, hybrid, and distance education, and also in other ways. So, at the ATS biennial meeting held in Denver in June 2018 , the member schools voted to authorize a complete rewrite of the Standards of Accreditation for the next generation. A Standards Redevelopment Task Force was appointed, and a two-year process was launched.

The redesign process has now been completed. The proposed new standards (www.ats.edu/uploads/accrediting/documents/standardsof-accreditation.pdf) will be voted on by the member schools at the ATS biennial meeting to be held on June 24, 2020 online (due to COVID), instead of in Vancouver as originally planned. [Post-session 
note: the proposed standards were voted affirmatively with no revisions at the ATS biennial meeting held via Zoom on June 24.]

We were fortunate to have three librarians on the nineteenmember Redevelopment Task Force: Tom Tanner, one of the ATS directors of accreditation and formerly the library director at Lincoln Christian University; Debbie Creamer, the senior director of accreditation at ATS and formerly the library director at Iliff School of Theology; and me, a member school representative appointed to the Task Force. Debbie and Tom were amazing contributors to this process, and I daresay we would not have this new set of standards at this time without their leadership. It was an honor for me to work with all of the amazing folks on the Task Force.

ATS emphasizes this mantra: the ATS Standards come from the membership, are written by the membership, are designed for the membership, and are approved by the membership. When a school is in the throes of a self-study process and evaluation visit, it is easy to lose sight of this fact and to feel as if the standards have somehow been imposed upon us. But the standards do not belong to ATS or to the Board of Commissioners; they belong to us all. In this peer-review process, the mutuality is baked into the process.

I would like to highlight five key changes in the proposed new standards. First, the new standards have been streamlined for "elegant simplicity." These proposed standards are much more succinct, with approximately 25\% of the word count of the 1996 standards. The 1996 standards had three sets of standards (the Institutional Standards, the Degree Program Standards, and the Educational Standard) totaling nineteen standards. The 2020 proposed redesign is a single set of standards, with ten standards total.

The structure of the new standards is a center with "bookends" of support on either side.

The center is focused on students. Standards 3-5 focus on Student Learning and Formation, Master's Degree Programs, and Doctoral Degree Programs, and Standards 6-8 address the programs and personnel most closely connected to students: Library and Information Services, Student Services, and Faculty. The "bookend" at the front end is Standard 1 on Mission and Integrity and Standard 2 on Planning and Evaluation, and the "bookend" on the other end is Standard 9 on Governance and Administration and Standard 10 on Institutional Resources. 
Second, these proposed standards focus on educational principles over institutional practices. They are intentionally more general in tone and content, with a higher level of abstraction. They have done away with the threshold rules that sometimes seemed arbitrary. For example: the 1996 standard's rule that no more than $15 \%$ of a school's MDiv admissions could be without a BA degree has gone away. Instead, under the proposed new standards, each school is expected to define its admission standards and to articulate its admission policy. The new Student Services Standard says that a school may admit students without an accredited BA "if the school documents through rigorous means that those students are prepared to do master's level work" (Standard 7.4).

Third, the new standards are designed to give each member school the flexibility and freedom to find the most appropriate ways to implement those educational principles in light of that school's unique mission and context.

Fourth, they emphasize educational quality rather than modality. The proposed standards do not consider any particular modality of educational delivery as normative. In other words, residential, online, distance, and hybrid forms of educational delivery are now treated equally in the standard. (The only modality not allowed is correspondence education.) Schools that have been approved for distance education will be able to offer any of their approved degrees in a fully online format (except the $\mathrm{PhD} / \mathrm{ThD}$ ) without extra petitions to ATS. The standards require all degree programs to demonstrate student learning outcomes and reflect educational quality, regardless of the teaching modality that is used.

Fifth, the new standards combine educational assessment and institutional evaluation into a unified section on evaluation (Standard 2.5-2.8). This standard emphasizes that evaluation should be simple, systematic, and sustainable. A school will be expected to articulate its mission, identify key educational and institutional outcomes, gather evidence related to each outcome by direct and indirect measures using both qualitative and quantitative data, engage stakeholders to analyze how well the evidence supports the outcome's achievement, and then use that analysis for educational and institutional improvement. This evaluation cycle is congruent with assessment in the old standards, so it should sound familiar.

The ATS redevelopment website offers two versions of the standards: one with just the text of the standards and one that is called 
"Standards with Self-Study Ideas" (www.ats.edu/uploads/accrediting/ documents/standards-of-accreditation-with-self-study-ideas.pdf). The latter version includes inset boxes that offer ideas for how a school might demonstrate compliance with the standard in its selfstudy. I would like to say a few words about how these self-study idea boxes function and what they contain. These ideas mostly use the word "might" to indicate that these are suggestions, not requirements. The idea boxes elucidate the standard; they provide a form of commentary on the standard. They offer how the standard might apply in various contexts, like embedded schools, or schools that have to meet US Department of Education Title IV requirements. They are intended to spark ideas for self-evaluation. They are not "rump" standards or subsidiary standards. The Task Force worked to ensure that these self-study idea boxes are illustrative. It is important to note that these self-study ideas are not actually part of the approved standards. The self-study ideas are approved by the Board of Commissioners, whereas the standards are voted upon by the membership.

We continue to have a standard specifically for libraries: Standard 6 on Library and Information Services. There was debate about whether libraries still need to have a separate standard, or whether it would be better to integrate the library within the text of another standard, like student learning. The Task Force decided to do both: the library has its own standard, and it is embedded at places in the other standards. For example, the Student Learning Standard says that curriculum development is collaborative between faculty, librarians, student services personnel, field educators, and others (Standard 3.7).

The new Library and Information Services Standard begins with a definition and then has three sections: Library Purpose and Role, Staffing and Evaluation, and Services and Resources. The Task Force sought to write a library standard that will be relevant across the membership, recognizing that our schools have differences in context and mission that lead to differing balances of physical collections and e-resources. Each institution will be expected to provide evidence that its way of fulfilling the standard provides quality graduate theological education in that school's context and for that school's constituency.

A key difference is that the proposed new standard emphasizes library services first, rather than putting collections first. "Librarians: 
provide reference services, help users navigate research resources, teach information literacy skills, support the scholarly and educational work of the school, and foster lifelong learning” (Standard 6.6). The new library standard requires a written statement "that identifies [the library's] purpose and role in the school and the ways it contributes to achieving the school's educational mission" (Standard 6.1).

Regarding staffing, standard 6.3 says: "Library and information services personnel are of sufficient number, [and] have appropriate qualifications and expertise...” Then the standard goes on to say that librarians are educational partners with faculty. They "play a significant and collaborative role in curriculum development, implementation, and evaluation" (6.2). They "are appropriately integrated into the school's leadership, faculty, and decision-making structures, including budgeting and strategic planning processes" (6.4). The selfstudy idea related to Standard 6 adds more specificity about staffing. It suggests that the school should describe its staff, their qualifications, and their expertise. "It is common for a collection development librarian to have subject matter expertise ... and for a library director to have graduate degrees in library science and in theological studies ... if the school expects different qualifications, it might ... describe how it evaluates its model."

The new library standard requires evaluation of library services and resources. The standard shifts the focus from measuring what our libraries hold (collection counts) to analyzing how effectively our patrons are utilizing the library's resources and services "in ways that are appropriate to the school's educational mission, degree programs, and educational modalities” (Standard 6.5).

The 1996 library standard required a collection development policy. The proposed new standard will require a collection development and access policy. It is suggested that the policy should address: the acquisition and weeding of print and electronic collections, how the library prioritizes expenditures, how it curates and evaluates consortial resources, and "it should demonstrate adequate research resources for students in all modalities and teaching locations" (selfstudy Idea box). An excellent example of such a policy is the Library Resource Access Guide that Eileen Saner and Karl Stutzman wrote for the Anabaptist Mennonite Biblical Seminary (libraryguides.ambs. edu/resourceaccesspolicy). Their policy uses the categories of "effi- 
cient discovery, expedited delivery, targeted acquisition, and preservation priorities."

If the new standards are approved at the ATS biennial meeting, they will become effective on July 1,2020. A process of grandfathering and education will come next. For the seventy accreditation visits scheduled to be held between fall 2020 and spring 2022, each school will be allowed to choose whether to use the 1996 standards or the new 2020 standards for their self-study process. For accreditation visits scheduled for fall 2022 and thereafter, every school must use the new 2020 standards. Everything else related to the standards is being rewritten to reflect the new standards: the Policies and Procedures of Accreditation (www.ats.edu/uploads/accrediting/documents/policies-and-procedures.pdf ) and the Commission Bylaws (www.ats.edu/uploads/accrediting/documents/commission-bylaws. pdf); Implementation Procedures (www.ats.edu/uploads/accrediting/documents/implementation-procedures.pdf); the Self-Study Handbook (www.ats.edu/uploads/accrediting/documents/self-studyhandbook.pdf); training materials for schools preparing for visits, and guidelines for evaluation team visits.

I would like to conclude with this quote from the library definition in the proposed new Standard 6: "Theological libraries are curated collections and instructional centers with librarians guiding research and organizing access to appropriate resources. Libraries and librarians partner with faculty in student learning and formation to serve schools' educational missions and to equip students to be effective and ethical users of information resources.” The Task Force wanted the standard to reflect the active and interactive nature of libraries and librarians. We hope these new standards, and the library standard in particular, will serve our schools well both now and into the future. 